\title{
Sistem Informasi Monitoring Perkembangan Anak di Sekolah Taman Kanak - kanak Berbasis Cloud
}

\author{
Putu Satya Saputra ${ }^{1}$, I Made Sukarsa², I Putu Agung Bayupati ${ }^{3}$ \\ Teknologi Informasi, Fakultas Teknik, Universitas Udayana \\ Kampus Unud, Bukit Jimbaran, Bali, Indonesia \\ satyasaputra45@yahoo.com ${ }^{1}$ \\ sukarsa@unud.ac.id² \\ bayuhelix@yahoo.com ${ }^{3}$
}

\begin{abstract}
Abstrak
Pendidikan merupakan sarana untuk memajukan sumber daya manusia. Mewujudkan kemajuan pendidikan, memerlukan suatu alat untuk mengelola data seperti data kurikulum, siswa maupun nilai. Alat tersebut nantinya dapat digunakan untuk mengontrol kegiatan siswa di sekolah sehingga hasil informasi dapat segera tersampaikan dan proses monitoring dapat berjalan efektif karena adanya komunikasi antara pihak sekolah dan orang tua. Sistem Informasi Monitoring Perkembangan Anak di Sekolah Taman Kanak - kanak Berbasis Cloud merupakan sebuah layanan Software As A Services (SaaS) berbasis web. Sistem informasi ini dibuat dengan menggunakan teknologi cloud yang memberikan fasilitas untuk melakukan pengelolaan berbagai data akademik seperti data siswa, nilai dan lain sebagainya. Layanan sistem informasi akademik berbasis cloud ini dapat diandalkan untuk beroperasi secara online tanpa memerlukan server dan instalasi untuk setiap sistem yang ada di sekolah. Penggunaan teknologi cloud dalam pembuatan aplikasi ini sudah dapat mempermudah proses manajemen data akademik dan data sekolah yang umumnya dilakukan secara konvensional. Hasil penelitian yang dilakukan dengan menyebar kuesioner menggunakan perhitungan skala likert menunjukkan lebih dari 50\% pengguna setuju dengan pernyataan yang sudah dibuat.
\end{abstract}

Kata Kunci : Sistem Informasi, Cloud Computing, Software As A Services.

\begin{abstract}
Education is a means to advance human resources. Achieving educational progress requires a tool for managing data such as curriculum data, students and grades. This tool can be used to control student activities in school so that the results can be delivered immediately and the monitoring process can run effectively because of communication between the school and parents. Child Development Monitoring Information System at Cloud-Based Kindergarten School is a Web-based Software As A Services (SaaS) service. This information system created by using cloud technology provides facilities to perform the management of various academic data such as student data, values and so forth. A cloud-based academic information system service that can be relied on to operate online without servers and installations for every system in school. The use of cloud technology in making this application is expected to further simplify the process of academic data management and school data that is generally done conventionally. The results of research conducted by spreading the questionnaire using Likert scale calculations show more than $50 \%$ of users agree with the statement already made.
\end{abstract}

Keywords : Information System, Cloud Computing, Software As A Services.

\section{Pendahuluan}

Sistem informasi akademik merupakan salah satu alat untuk pengelolaan data pendidikan dan mampu memberikan fasilitas untuk melakukan pengelolaan berbagai data akademik seperti data siswa, nilai, guru dan lain sebagainya. Sistem monitoring pada sistem informasi akademik akan membantu pengambilan keputusan dan pemantauan khusus terhadap siswa [1]. 
Monitoring (pemantauan) merupakan sebuah proses penilaian kualitas kinerja sistem dari waktu ke waktu. Pemantauan ini dilakukan secara berkelanjutan sejalan dengan kegiatan usaha yang mencakup kegiatan sehari - hari. Penggunaan sistem monitoring bertujuan untuk mengontrol, mengawasi serta mengecek sejumlah aktivitas yang telah dilakukan [2].

Kegiatan monitoring siswa di sekolah masih kurang menjangkau orang tua atau wali murid dikarenakan masih terbatas pada pihak sekolah. Setiap kegiatan siswa di sekolah perlu diinformasikan kepada orang tua atau wali murid sebagai bahan pertimbangan untuk mendidik anak dirumah. Informasi yang diperlukan orang tua atau wali murid membutuhkan suatu sarana untuk mengakomodasi penyampaian informasi secara mudah dan cepat. Dalam hal ini, maka diperlukan sistem monitoring pada sistem informasi akademik untuk mengontrol kegiatan siswa di sekolah yang dapat menjangkau hampir seluruh daerah sehingga hasil informasi dapat segera tersampaikan dan proses monitoring dapat berjalan efektif karena adanya komunikasi antara pihak sekolah dan orang tua [3].

Sistem informasi akademik pada umumnya memerlukan server dan instalasi untuk setiap sistem yang ada disekolah. Teknologi sistem informasi yang berbasis cloud merupakan sebuah teknologi yang menjadikan internet sebagai pusat server untuk mengelola data serta aplikasi pengguna. Teknologi cloud juga mengizinkan akses pengguna untuk dapat menjalankan program tanpa instalasi data diri pribadi melalui komputer dengan akses internet. Alasan menggunakan teknologi cloud adalah data yang tersedia dapat diakses lebih mudah dengan biaya yang jauh lebih rendah karena dapat digunakan untuk banyak sekolah, kemudahan akses, dan memungkinkan peluang untuk melakukan integrasi.

Terkait dengan customer relationship management, Seeman, D., et al. [4] telah mengusulkan penelitian dengan judul "Customer Relationship Management in Higher Education Using Information Systems to Improve the Student-School Relationship". The North Carolina Community College System (NCCCS) merupakan sistem pendidikan terbesar ke-3 di Amerika Serikat. NCCCS melayani lebih dari 750.000 mahasiswa setiap tahun di 59 lembaga negara yang menerapkan CRM (Customer Relationship Management). Hasil implementasi CRM dalam perguruan tinggi pada NCCCS membantu perguruan tinggi untuk meningkatkan loyalitas mahasiswa sehingga berdampak pada peningkatan daya saing dan profit perguruan tinggi.

Penelitian berikutnya Novianti, A., et al. [5] dengan judul "Sistem Informasi Sekolah Dasar Berbasis SMS". Sistem informasi ini mampu mengirimkan sms data absensi siswa, broadcast SMS kegiatan ke semua orang tua, melakukan akses data siswa dan data kegiatan sekolah. Informasi kegiatan di sekolah dikirim ke semua orang tua apabila akan diadakan kegiatan. Selain itu, jika orang tua ingin mengetahui informasi kegiatan dan absensi, dapat diminta dengan mengirim sms ke server.

Penelitian Setiyadi, A., et al. [6] dengan judul "Sistem Informasi Pengumuman Program Studi Di Perguruan Tinggi X". Sistem informasi pengumuman ini mampu menampilkan pengumuman dosen dan sekretariat program studi secara digital dengan memasukkan pengumuman ke dalam sistem. Pengumuman tersebut dapat dilihat di setiap layar televisi atau monitor yang tersedia di area kampus sehingga proses penyampaian informasi menjadi lebih efektif dan efisien dibandingkan dengan media cetak.

Penelitian lainnya dari Arfan, M. [7] yang berjudul "Model Implementasi Centralized Authentication Service pada Sistem Software As A Service". Layanan cloud sistem yang telah dibuat ditambahkan sistem otentikasi terpusat pada aplikasi cloud dengan menggunakan protokol single sign-on. Tujuan otentifikasi pada aplikasi adalah untuk meningkatkan keamanan pengguna dan penyedia layanan sistem cloud.

Diadaptasikan dari penelitian diatas, paper ini mengusulkan "Sistem Informasi Monitoring Perkembangan Anak di Sekolah Taman Kanak - kanak Berbasis Cloud". Sistem informasi ini bertujuan untuk membantu orang tua memonitoring dan melihat perkembangan anaknya di sekolah. Manfaat bagi sekolah dan yayasan yang menggunakan sistem cloud dapat mempermudah pendataan guru, siswa, pegawai, kegiatan sekolah, nilai, laporan dan kegiatan akademik sekolah hanya dalam satu sistem informasi. 


\section{Metode Penelitian}

Metodologi penelitian yang digunakan yaitu menggunakan metode prototype. Metodologi ini digunakan karena diperlukan validasi dari pengguna apakah sistem informasi yang dibuat sudah sesuai dengan yang diharapkan. Tahapan metode penelitian prototype Sistem Informasi Monitoring Perkembangan Anak di Sekolah Taman Kanak - kanak Berbasis Cloud yaitu sebagai berikut.

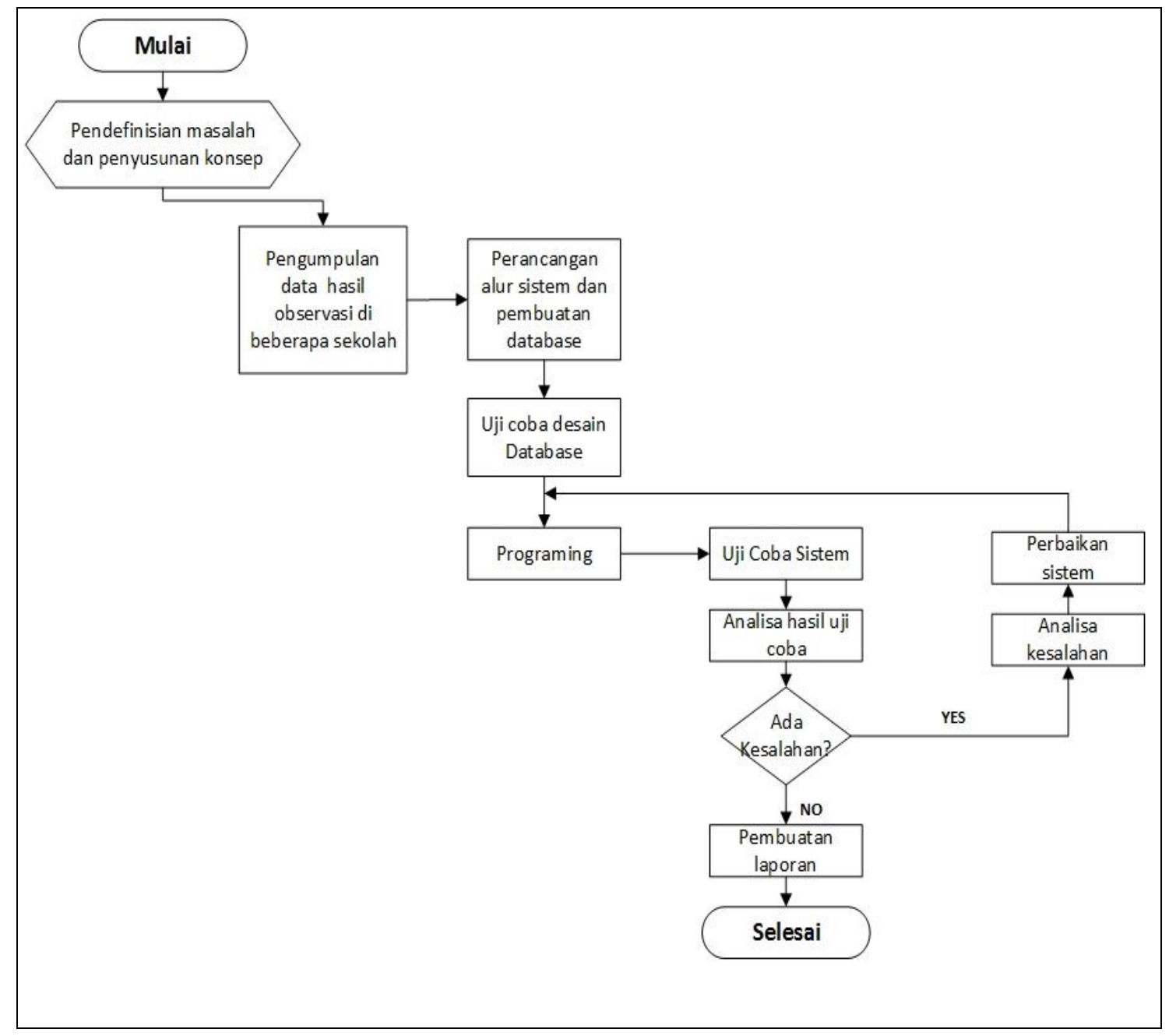

\section{Gambar 1. Tahapan Model Prototype}

Gambar 1 merupakan tahapan alur penelitian yang dilakukan dengan menggunakan metode prototype. Alur metode prototype yang digunakan dalam membuat penelitian ini dapat dijelaskan sebagai berikut.

Tahap awal dalam membangun sistem ini adalah mendefinisikan masalah dan menyusun konsep penelitian. Data kuantitatif dan data observasi dikumpulkan setelah tahap awal dilakukan. Data ini mencangkup data dari beberapa sekolah TK yang ada di Jimbaran Kecamatan Kuta Selatan Bali dan data hasil wawancara langsung dengan pihak terkait. Studi literatur berguna untuk memberikan penjelasan mengenai teori atau konsep dalam sebuah penelitian.

Tahap selanjutnya yaitu mulai merancang alur sistem yang akan dibuat. Alur sistem sangat berperan penting karena dengan alur tersebut suatu sistem dapat dinyatakan sebagai sistem yang baik atau buruk. Pembuatan database dilakukan setelah perancangan alur dengan menggunakan DBMS MySQL.Pengerjaan aplikasi, meliputi implementasi alur dan user interface yang telah dirancangkan sebelumnya. Pengujian sistem dengan cara melakukan simulasi penggunaan sesuai dengan kenyataan di lapangan. 
Tahap analisa hasil uji coba ini bertujuan untuk mengetahui apakah sistem layak untuk digunakan, adakah fungsi yang masih belum berjalan, sampai pada pencarian kekurangan sistem. Sistem ini diharapkan dapat bekerja dengan baik dan memberikan hasil yang akurat serta user friendly.

\subsection{Gambaran Umum Sistem}

Gambaran umum dari Sistem Informasi Monitoring Perkembangan Anak di Sekolah Taman Kanak - kanak Berbasis Cloud yang dibuat dapat dijelaskan pada gambar berikut ini.

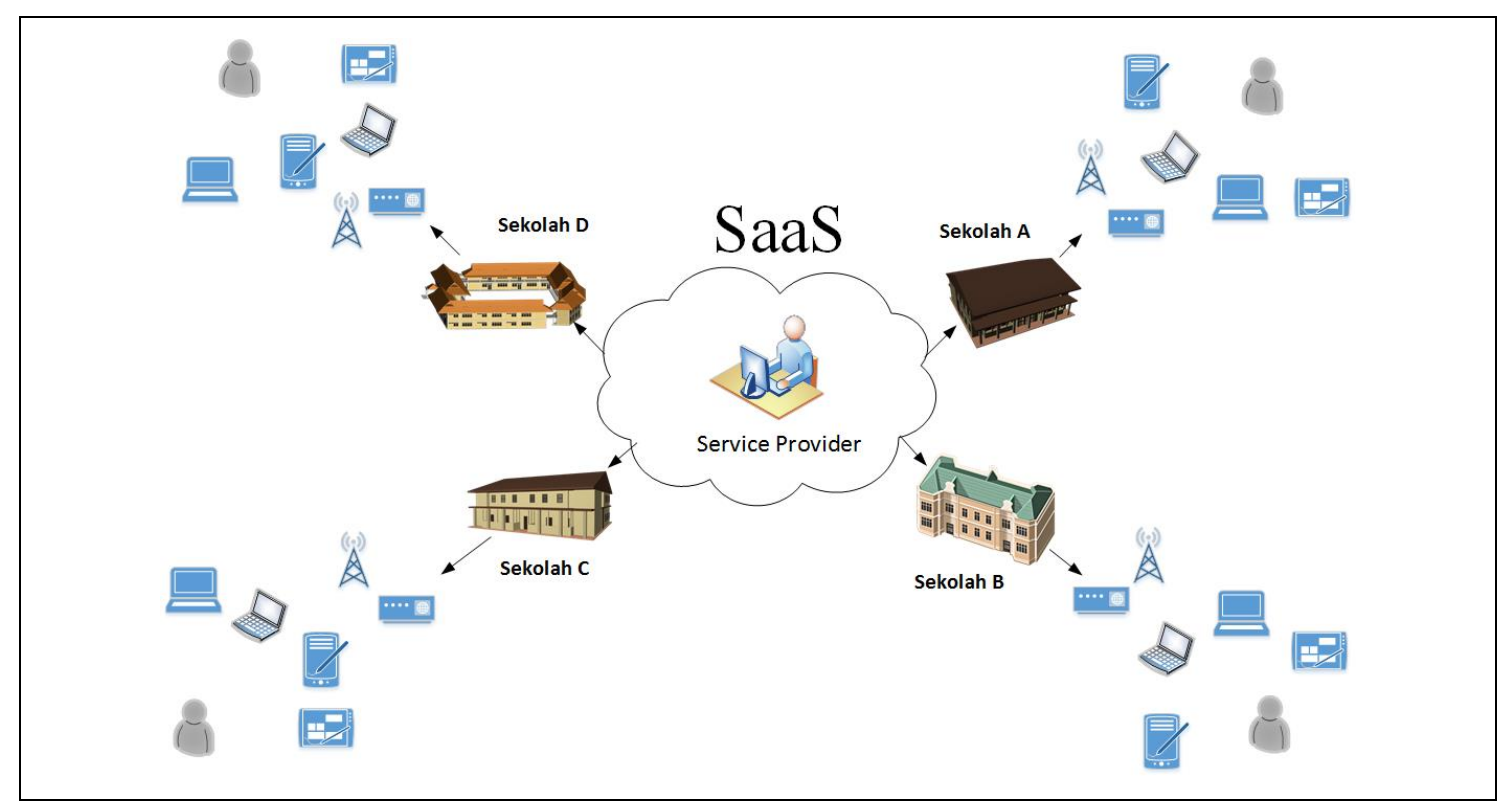

Gambar 2. Gambaran Umum Sistem

Gambar 2 diatas menjelaskan gambaran umum dari Sistem Informasi Monitoring Perkembangan Anak di Sekolah Taman Kanak - kanak Berbasis Cloud. Sistem informasi ini menggunakan teknologi Software as a Service (SaaS) dan dapat diakses melalui web browser. Software as a Service (SaaS) merupakan perangkat lunak berbentuk layanan yang dikembangkan dan dikelola oleh service provider untuk digunakan end user (pengguna) melalui internet. Service provider atau super admin dapat memantau pertumbuhan data dan memberikan approve kepada sekolah yang mendaftar. Masing - masing sekolah yang sudah terdaftar dikelola oleh admin setiap sekolah. Admin sekolah dapat mengelola data siswa, pegawai, wali kelas, kelas, materi pembelajaran, berita sekolah dan lain sebagainya. Wali kelas dapat menambahkan laporan perkembangan siswa setiap minggu beserta laporan hasil belajar setiap semester. Laporan perkembangan dan laporan hasil belajar siswa dapat dilihat oleh orang tua siswa melalui email maupun melalui sistem informasi.

\subsection{Diagram Konteks}

Diagram konteks dari Sistem Informasi Monitoring Perkembangan Anak di Sekolah Taman Kanak - kanak Berbasis Cloud yang dibuat dapat dijelaskan pada gambar berikut ini. 


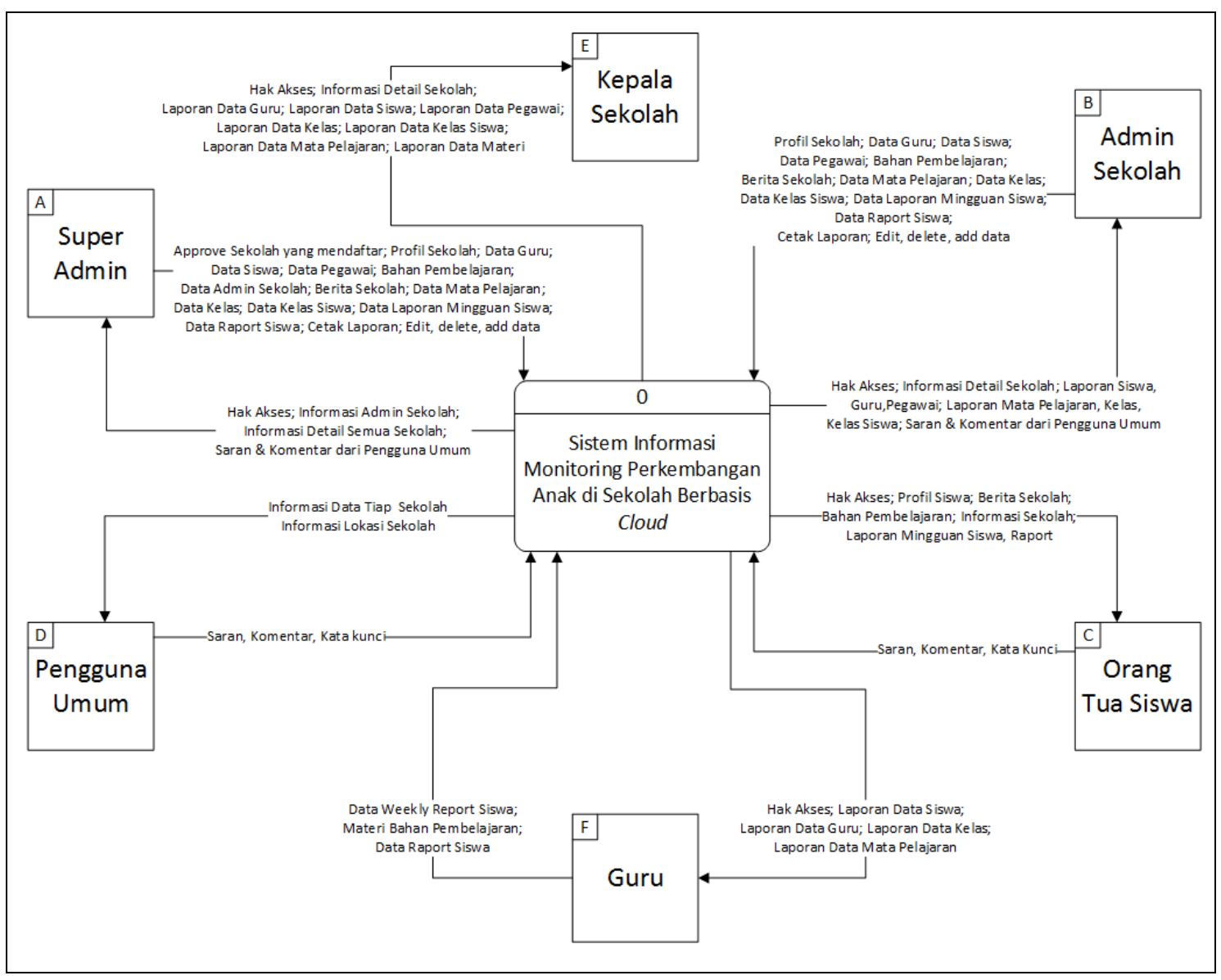

Gambar 3. Diagram Konteks

Diagram konteks pada Gambar 3 menunjukkan bahwa dalam sistem informasi ini terdapat 6 entitas, yaitu super admin (service provider), admin sekolah, kepala sekolah, guru, orang tua siswa dan pengguna umum. Hubungan antara entitas-entitas tersebut dengan sistem informasi ini adalah sebagai berikut.

a. Super Admin (Service Provider)

Super admin adalah pengguna sistem yang memiliki hak akses untuk melakukan manipulasi data baik itu tambah, edit dan hapus seluruh data yang ada pada sistem. Super admin dapat memberi approve untuk sekolah yang mendaftar ke sistem.

b. Admin Sekolah

Admin sekolah adalah pengguna sistem yang memiliki hak akses untuk melakukan manipulasi data seperti menampilkan pengumuman sekolah, menambah data guru, siswa dan lain sebagainya. Perbedaan admin sekolah dan super admin, admin sekolah hanya dapat melakukan manajemen data pada satu sekolah atau sekolah yang dinaunginya. Admin sekolah tidak bisa melihat dan memanipulasi data pada sekolah lain.

c. Kepala Sekolah

Kepala Sekolah memiliki hak akses untuk menerima semua laporan seperti profil sekolah, laporan siswa, laporan guru, laporan pegawai, laporan mata pelajaran, laporan kelompok belajar dan laporan kelas siswa.

d. Wali Kelas

Wali kelas merupakan pengguna sistem yang memiliki hak akses untuk menginputkan laporan perkembangan siswa seperti data weekly report (laporan mingguan) dan raport siswa. Wali kelas juga dapat menambah materi pembelajaran ke sistem. 


\section{e. Orang Tua Siswa}

Orang tua siswa adalah pengguna sistem yang memiliki hak akses untuk melihat perkembangan anaknya seperti data weekly report (laporan mingguan) dan raport siswa yang telah di inputkan oleh wali kelas. Orag tua siswa juga dapat mengunduh materi pembelajaran yang ada disekolah. f. Pengguna Umum

Pengguna umum adalah pengguna sistem yang memiliki hak akses hanya untuk melihat data profil masing - masing sekolah melalui web public. Pengguna umum memberikan interaksi kepada sistem dengan cara mengisi kata kunci nama sekolah pada kolom search yang nantinya akan direspon oleh sistem. Selain itu pengguna umum juga dapat memberi komentar dan saran pada form komentar yang disediakan.

\section{Kajian Pustaka}

Kajian pustaka merupakan bahan yang dijadikan sebagai acuan dalam pembuatan penelitian diantaranya sebagai berikut ini.

\subsection{Cloud Computing}

Menurut Hewit, "Teknologi cloud computing merupakan teknologi dimana sebagian besar proses dan komputasi terletak di jaringan internet sehingga memungkinkan pengguna dapat mengakses layanan yang diperlukan dari manapun dan kapan pun" [8].

Firmansyah berpendapat bahwa, "Cloud computing merupakan teknologi yang memungkinkan resource IT digunakan untuk beragam platform, kode program, dan aplikasi yang berbeda, agar dapat terintegrasi dalam penggunaan dan pelayanan" [9].

Berdasarkan pemaparan dari berbagai sumber dapat dikatakan bahwa cloud computing adalah model layanan untuk memanfaatkan bersama suatu sumberdaya komputasi yang terkonfigurasi (misalnya, jaringan, server, penyimpanan, aplikasi, dan layanan) yang dapat secara cepat dijalankan melalui internet. Salah satu keunggulan teknologi cloud adalah memungkinkan pengguna untuk menyimpan data secara terpusat di satu server berdasarkan layanan yang disediakan oleh penyedia layanan cloud computing.

\subsection{Sistem Informasi}

Sistem informasi merupakan kombinasi teknologi, prosedur kerja, informasi, aktivitas orang yang diorganisasikan untuk mencapai suatu tujuan dalam organisasi dan pelaku bisnis [10]. Sistem informasi dapat memberikan berbagai manfaat baik bagi internal organisasi maupun pihak luar (misalnya pelanggan). Beberapa contoh penerapan sistem informasi adalah Amazon (http://www.amazon.com) merupakan sebuah toko online yang memungkinkan seseorang dapat melihat daftar buku atau produk lain melalui kata kunci yang dimasukkan dalam fasilitas pencari. FedEx (http://www.fedex.com), perusahaan berskala internasional yang bergerak pada jasa pengiriman dokumen atau barang. Ryan Air (http://www.ryanair.com), perusahaan penerbangan yang berbasis di Eropa, menyediakan sarana web yang memungkinkan calon penumpang pesawat terbang memesan tiket tanpa harus datang ke kantor biro pelayanan penjualan terlebih dahulu. Sejumlah perguruan tinggi di Indonesia memberikan layanan yang memungkinkan mahasiswa melihat nilai - nilai matakuliah yang pernah ditempuhnya melalui internet dan bahkan melalui perangkat ponsel [11].

\subsection{Metode Prototype}

Prototype merupakan metodologi pengembangan software yang menitikberatkan pada pendekatan aspek desain, fungsi dan user-interface. Developer dan user fokus pada user interface dan bersama-sama mendefinisikan spesifikasi, fungsi, desain dan bagaimana software bekerja. Developer dan user bertemu dan melakukan komunikasi dan menentukan tujuan umum, kebutuhan yang diketahui dan gambaran bagian-bagian yang akan dibutuhkan. Developer mengumpulkan detail dari kebutuhan dan memberikan suatu gambaran dengan cetak biru (prototype). Dari proses tersebut akan diketahui detail-detail yang harus dikembangkan atau ditambahkan oleh developer terhadap cetak biru, atau menghapus detail-detail yang tidak diperlukan oleh user. Proses akan terjadi terus menerus sehingga produk sesuai dengan keinginan dari user [12]. 


\subsection{Software as a Service (SaaS)}

Software as a Service (SaaS) adalah layanan dari cloud computing dimana pelanggan dapat menggunakan software (perangkat lunak) yang telah disediakan oleh cloud provider. Pelanggan cukup tahu bahwa perangkat lunak bisa berjalan dan bisa digunakan dengan baik. Contoh layanan Software as a Service adalah Google Docs, Gmail, Yahoo Mail, Facebook, Skype dan lain sebagainya. Keuntungan dari layanan Software as a Service ini adalah pengguna berlangganan ke cloud provider (penyedia layanan) dan membayar berdasarkan pemakaian sehingga pengguna tidak perlu membeli lisensi software [13].

\subsection{Skala Likert}

Skala likert merupakan suatu metode untuk memberi skor pada indeks berdasarkan struktur intensitas pertanyaan - pertanyaan yang telah dibuat oleh peneliti. Bentuk jawaban dari skala likert yaitu 5 = sangat setuju, $4=$ setuju, 3 = netral, 2 = tidak setuju, 1 = sangat tidak setuju [14].

\section{Hasil dan Pembahasan}

Hasil dan pembahasan berisikan tentang pembahasan dari sistem yang telah dirancang dan dilakukan pengujian.

\subsection{Rancangan Database}

Hubungan antar tabel pada rancangan database sistem informasi monitoring perkembangan anak di sekolah taman kanak - kanak berbasis cloud dapat dilihat pada Gambar 4.

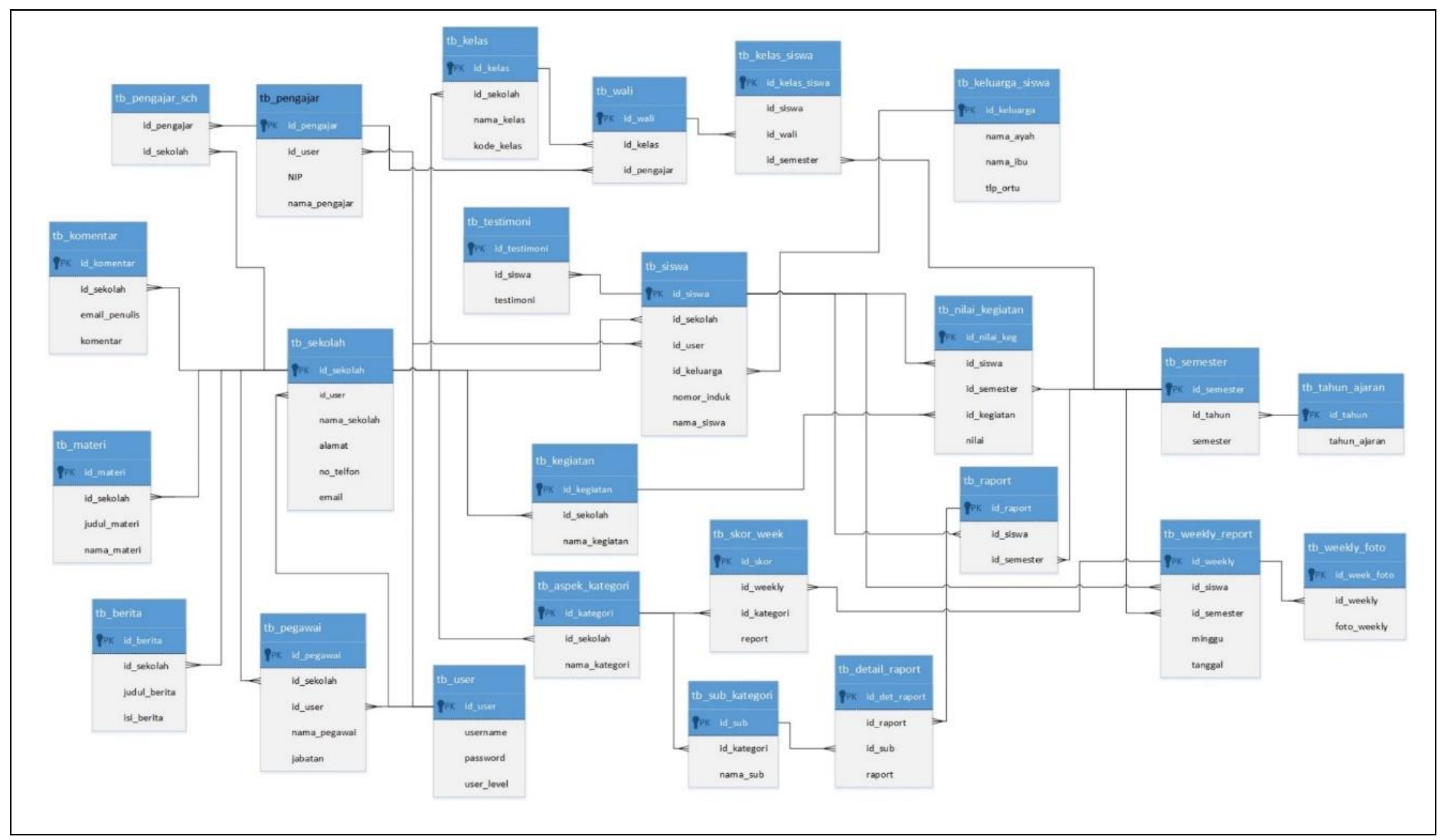

Gambar 4. Struktur Tabel

Gambar 4 adalah rancangan database dalam bentuk skema database. Tabel utama yang terdapat pada database tersebut antara lain tabel sekolah, tabel siswa yang berisi data siswa, tabel user digunakan untuk menyimpan data user dan admin, tabel pengajar, tabel nilai dan nilai kegiatan digunakan untuk menyimpan data raport siswa, tabel weekly yaitu tabel yang berisi data laporan perkembangan siswa setiap minggu. 


\subsection{Hasil Tampilan Sistem informasi}

Hasil tampilan sistem informasi dapat diakses melalui web browser. Berikut merupakan hasil uji coba sistem informasi monitoring perkembangan anak di sekolah taman kanak - kanak berbasis cloud.

\subsubsection{Tampilan Awal}

Antarmuka tampilan awal (home) merupakan web public yang menampilkan informasi dan deskripsi singkat tentang web ini. Web publik ini dapat di akses dan di lihat oleh semua orang/entitas tanpa perlu login ke sistem. Gambar 3 menunjukkan tampilan awal sistem informasi dengan beberapa navigas menu untuk memudahkan pengguna dalam mengakses informasi sekolah.

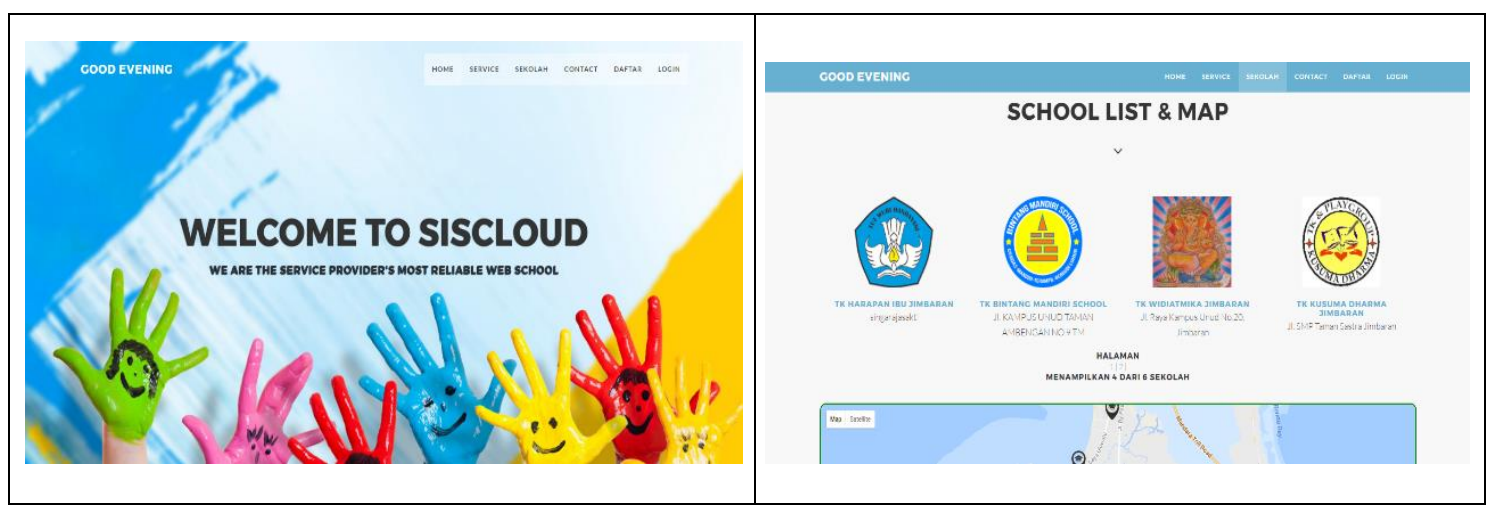

Gambar 5. Halaman Awal

Gambar 5 merupakan web public yang menampilkan informasi masing - masing sekolah. Web publik ini dapat di akses dan di lihat oleh semua orang/entitas tanpa perlu login ke sistem. Gambar merupakan tampilan menu utama saat masuk ke dalam web. Pengguna dapat melakukan klik pada link sekolah untuk melihat seluruh sekolah yang telah terdaftar di dalam cloud.

\subsubsection{Tampilan Super Admin (Service Provider) dan Admin Sekolah}

Masing - masing sekolah memiliki admin sekolah untuk memanajemen setiap sekolah. Admin sekolah dapat melakukan berbagai hal seperti melengkapi profil dan informasi sekolah, memanajemen data siswa, pegawai dan guru, melakukan update berita dan yang lainnya.

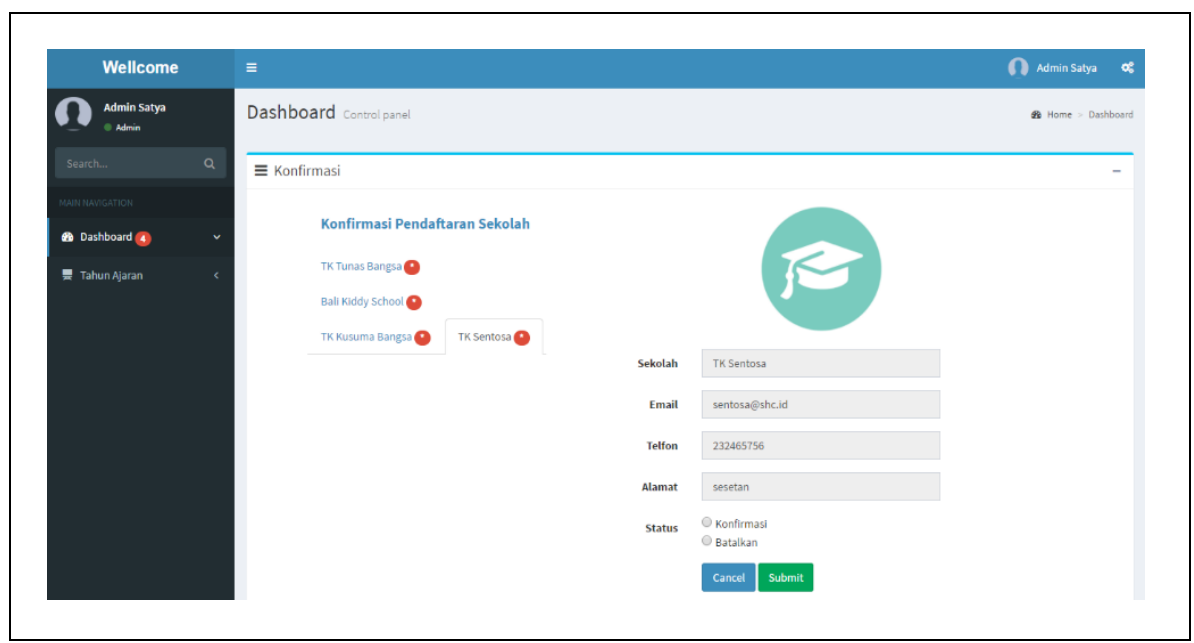

Gambar 6. Tampilan Super Admin (Service Provider) 
Admin atau super admin merupakan administrator sistem yang sesungguhnya. Super Admin dapat masuk ke masing - masing sekolah dan melakukan manipulasi data. Selain itu Super admin akan memberikan approve apabila terdapat sekolah yang mendaftar ke sistem.

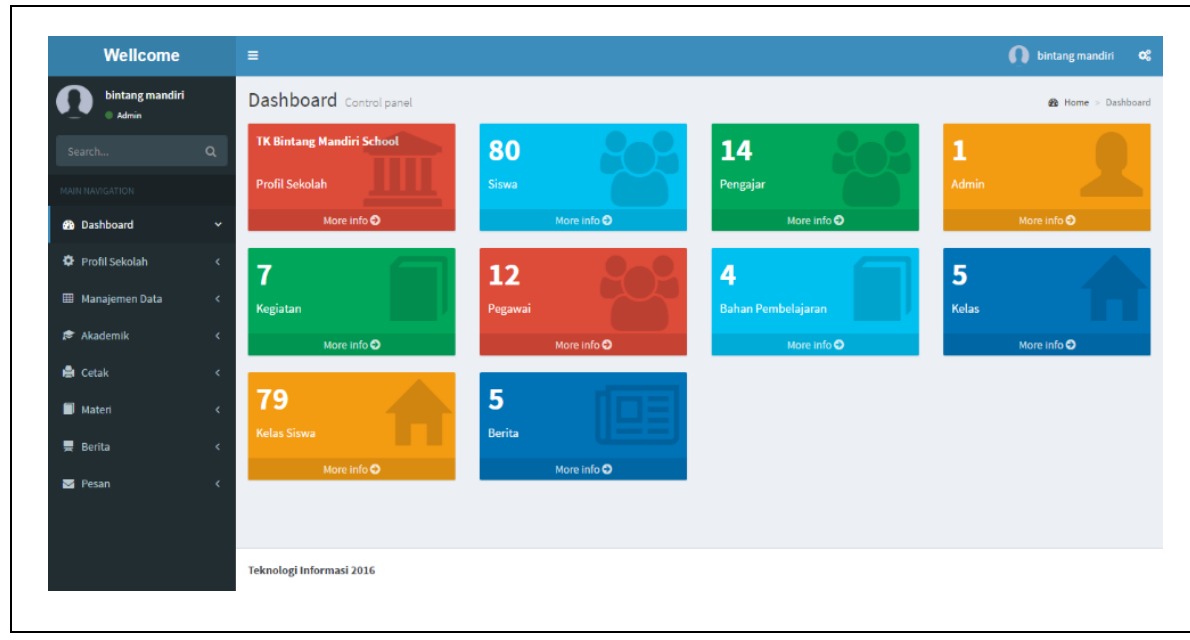

Gambar 7. Tampilan Admin Sekolah

\subsubsection{Tampilan Wali Kelas dan Orang Tua Siswa}

Hasil dari sistem ini berupa tampilan page orang tua siswa. Orang tua siswa dapat melihat perkembangan anaknya melalui web dan melakukan login terlebih dahulu. Perkembangan yang dimaksud berupa weekly report, raport siswa, berita, foto, materi pembelajaran dan yang lainnya.

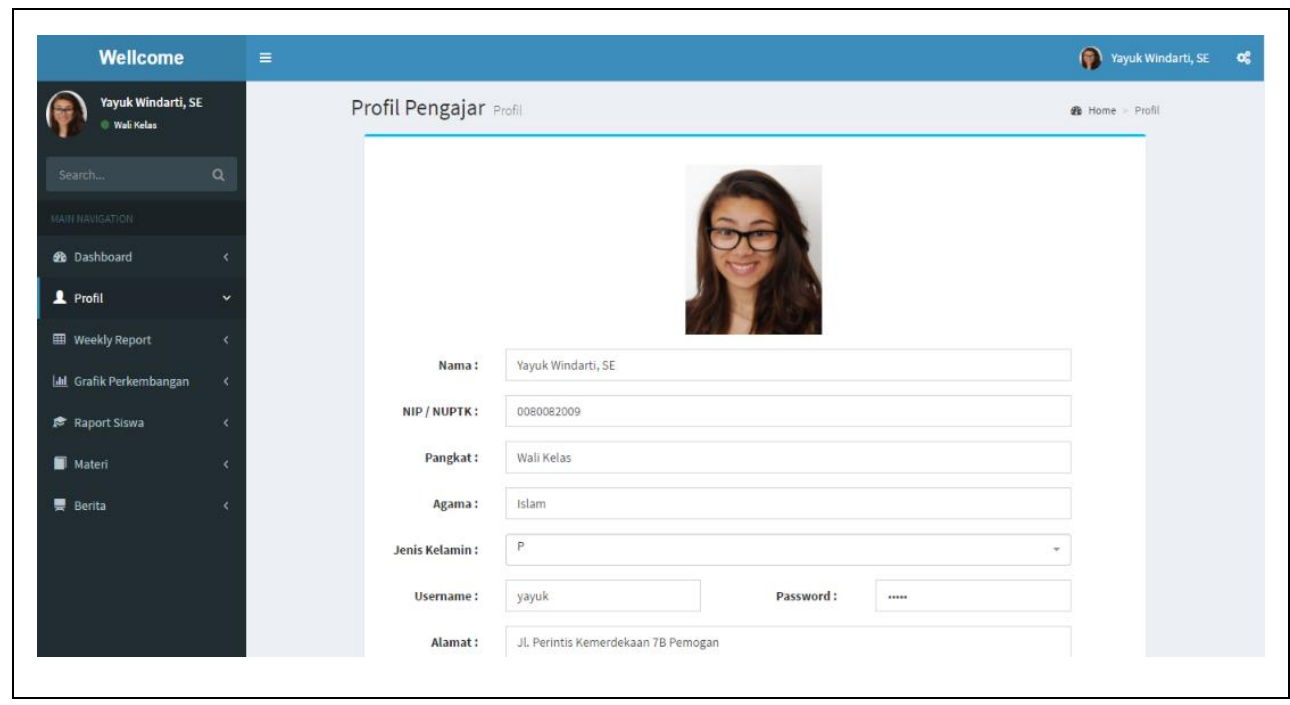

Gambar 8. Tampilan Halaman Wali Kelas 


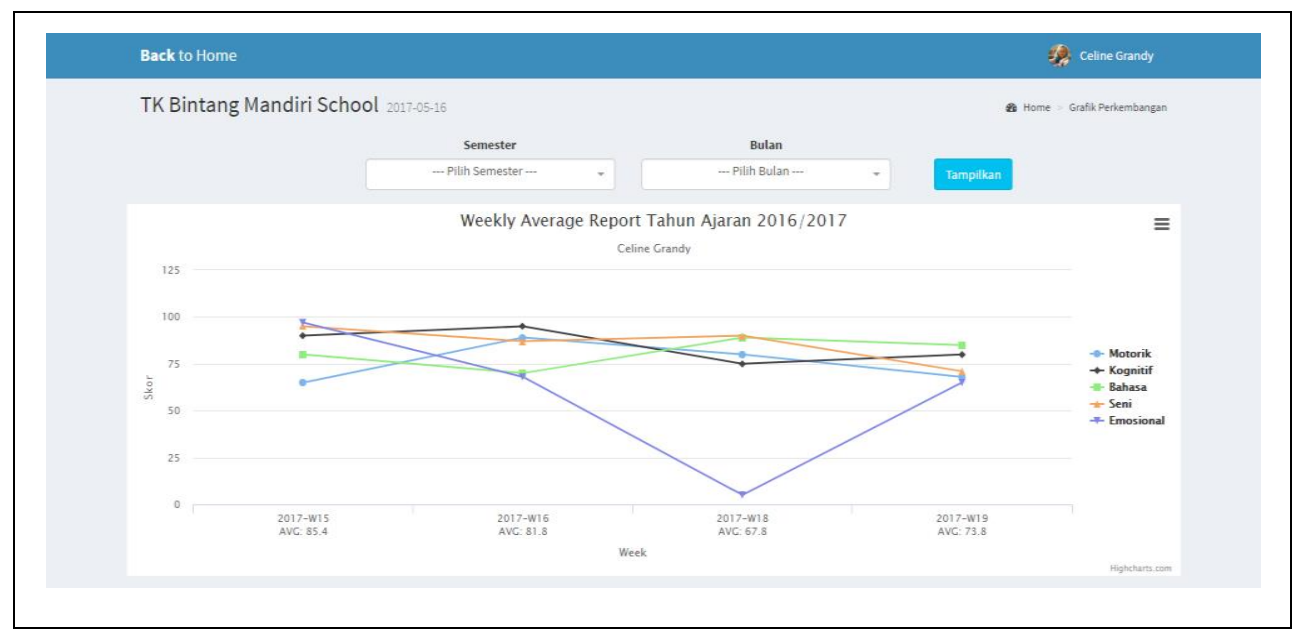

Gambar 9. Tampilan Grafik Perkembangan Siswa

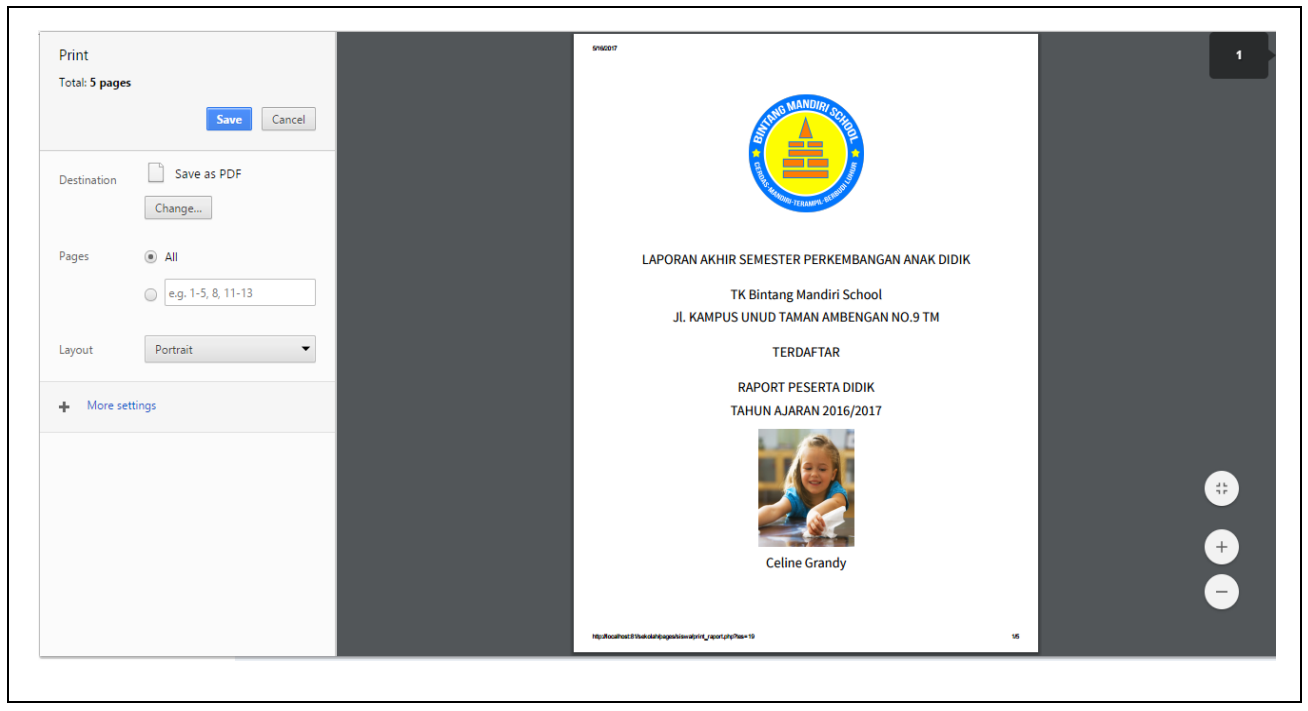

Gambar 10. Tampilan Halaman Raport Siswa

\subsection{Pengujian Kesesuaian Sistem}

Kesesuaian aplikasi diuji dengan menggunakan kuesioner yang disebar kepada 16 responden. Metode yang digunakan untuk menghitung hasil dari kuesioner adalah metode skala likert. Hasil dari kuesioner tersebut setelah dihitung yaitu responden sangat setuju dengan sistem bahwa sistem informasi telah berhasil berjalan dengan keinginan pengguna. Pengujian menggunakan 5 kategori jawaban, setiap jawaban memiliki nilai.
a. Sangat Tidak Setuju $=1$
b. Tidak Setuju $=2$
c. Cukup $=3$
d. Setuju $=4$
e. Sangat Setuju $=5$ 


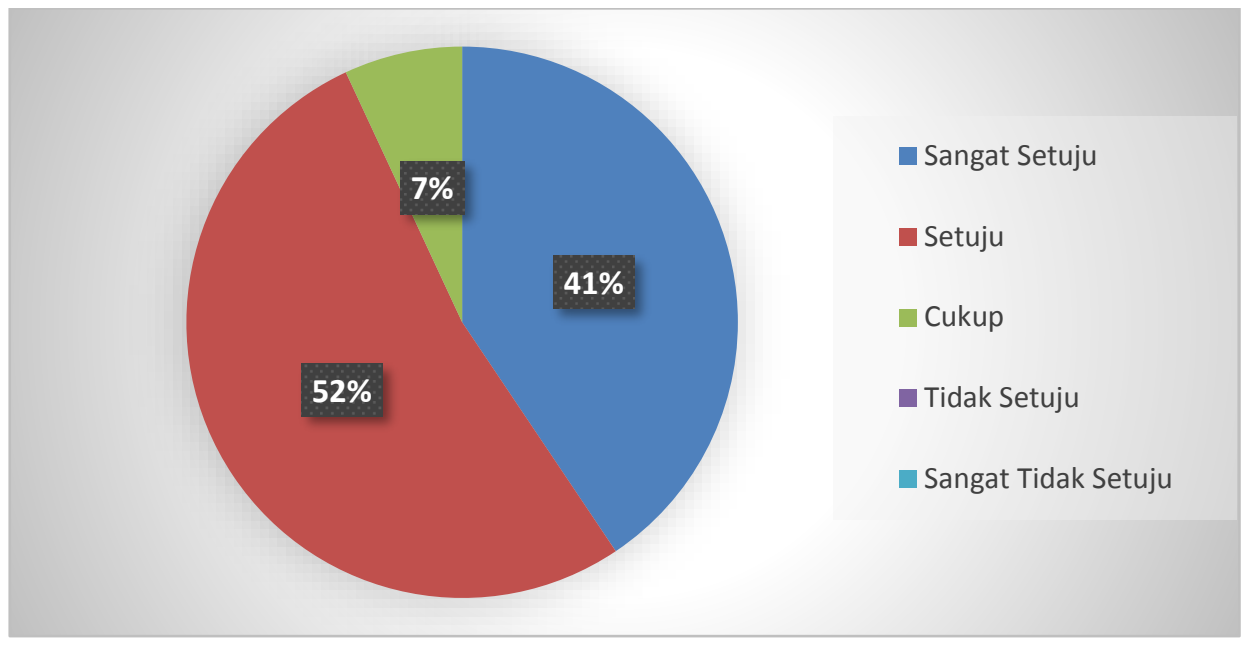

Gambar 11. Diagram Hasil Uji Coba

Berdasarkan diagram diatas maka dapat ditarik kesimpulan sebagai berikut:

a. Jumlah responden sebanyak 16 orang.

b. Jumlah pertanyaan pada 11 aspek.

c. Responden yang memilih sangat setuju sebanyak 72 dan hasil persentase sebesar: persentase $=(\text { rata-rata skor/jumlah responden })^{*} 100 \%$ $=41 \%$

d. Responden yang memilih setuju sebanyak 94 dan hasil persentase sebesar: persentase $=(\text { rata-rata skor/jumlah responden })^{*} 100 \%$ $=53 \%$

e. Responden yang memilih cukup sebanyak 13 dan hasil persentase sebesar: persentase $=(\text { rata-rata skor/jumlah responden })^{*} 100 \%$ $=7 \%$

f. Responden yang memilih tidak setuju sebanyak 0 dan hasil persentase sebesar: persentase $=(\text { rata-rata skor/jumlah responden })^{*} 100 \%$ $=0 \%$

g. Responden yang memilih sangat tidak setuju sebanyak 0 dan hasil persentase sebesar: persentase $=(\text { rata-rata skor/jumlah responden })^{\star} 100 \%$ $=0 \%$

\section{Kesimpulan}

Sistem Informasi Monitoring Perkembangan Anak di Sekolah Taman Kanak - kanak berbasis cloud merupakan sebuah layanan Software As A Services (SaaS) berbasis web yang dapat memudahkan pengguna untuk mengakses data akademik dan sekolah. Hal tersebut dapat dilihat pada hasil analisa kuesioner dari masing-masing pengguna. Lebih dari 50\% pengguna memilih setuju dan $41 \%$ memilih sangat setuju dengan pernyataan yang telah dibuat.

Sistem Informasi Monitoring Perkembangan Anak di Sekolah Taman Kanak - kanak berbasis Cloud dapat melakukan monitoring terhadap anak melalui weekly report (laporan mingguan) dan LHB (laporan hasil belajar) pada akhir semester. Weekly report (laporan mingguan) tersebut berisi laporan kategori yang dimiliki setiap sekolah misalnya seperti kategori motorik, kognitif, bahasa, seni, sosial emosional dan skor setiap kategori. Skor tersebut akan ditampilkan dalam bentuk grafik untuk memudahkan orang tua melihat perkembangan anak setiap minggunya.

\section{Daftar Pustaka}

[1] D. Y. Thomas Afrizal, "'Analisa Perancangan Sistem Informasi Pendataan Pendidikan KOta D,"' Tek. Inform. Univ. Indraprasta PGRI Jakarta, pp. 6-8, 2015.

[2] F. S. Prambudi, "Sistem Informasi Monitoring Siswa Bermasalah Berbasis Web dan SMS Gateway (Studi Kasus: SMA Negeri 2 Trenggalek)," J. JSIKA, vol. 1, 2012.

[3] P. W. Wirawan, "Integrasi Sistem Informasi Akademik dengan Sistem Monitoring Prestasi 
Akademik untuk Pengelolaan Sekolah," J. Ekon. Manaj. Akunt., vol. 24, 2016.

[4] E. D. Seeman and M. O'Hara, "Customer relationship management in higher education," Campus-Wide Inf. Syst., vol. 23, no. 1, pp. 24-34, 2006.

[5] A. Novianti, A. Fauzijah, R. Masalah, and B. Masalah, "Sistem Informasi Sekolah Dasar Berbasis Sms," Sist. Inf. Sekol. Dasar Berbas. Sms, vol. 2009, no. Snati, 2009.

[6] A. Setiadi, "Sistem Informasi Pengumuman Program Studi Di Perguruan Tinggi X," Lontar Komput. J. IIm. Teknol. Inf., vol. 8, no. pp.879-889, 2017.

[7] M. Arfan, "Model Implementasi Centralized Authentication Service pada Sistem Software As A Service," Jnteti, vol. 3, no. 1, 2014.

[8] C. Hewitt, "ORGs for scalable, robust, privacy-friendly client cloud computing," IEEE Internet Comput., vol. 12, no. 5, pp. 96-99, 2008.

[9] R. A. Firmansyah, "Desain Integrasi Learning Content Management System Pada CloudBase Sistem Informasi Sekolah," Stmik Stikom, pp. 7-12, 2013.

[10] I. D. Made, A. Baskara, and I. K. B. Sandika, "Sistem Informasi Manajemen Sebagai Alat Pengelolaan Penelitian Dosen," Lontar Komput., vol. 7, no. 1, pp. 726-735, 2016.

[11] A. Kadir, Dasar Perancangan \& Implementasi Database Relasional. Yogyakarta : Penerbit Andi Offset, 2008.

[12] M. Yazdi, "E-Learning Sebagai Media Pembelajaran Interaktif Berbasis Teknologi Informasi," J. IIm. Foristek, vol. 2, no. 1, pp. 143-152, 2012.

[13] A. Budiyanto, "Pengantar Cloud Computing," Cloud Indones. Jakarta, pp. 1-10, 2012.

[14] Muhammad Ali, "Pengembangan Media pembelajaran Interaktif Mata Kuliah Medan Elektromagnetik," J. Edukasi@ Elektro, vol. 5, no. 1, pp. 11-18, 2009. 